\title{
Rapid in situ settlement following spawning by Acropora corals at Ishigaki, southern Japan
}

\author{
Go Suzuki*, Seiji Arakaki, Takeshi Hayashibara
}

Ishigaki Tropical Station, Seikai National Fisheries Research Institute, Fisheries Research Agency, Okinawa 907-0451, Japan

\begin{abstract}
The principal role of larval recruitment in reef corals is still unknown: it could be for selfrecruitment or long-range dispersal. In this study, peak settlement period, which is ecologically (i.e. demographically) important, was estimated in the field by counting the number of settled corals every $3 \mathrm{~d}$ after a mass-spawning of Acropora corals. We found that $\sim 90 \%$ of the total recruits settled within $8 \mathrm{~d}$ after spawning. The number of swimming larvae also peaked from the fifth to the seventh day after spawning and decreased rapidly on the ninth day. Although we could not determine whether the coral larvae remained around the natal reef or if larval supply from upstream regions concentrated in this study area, no multiple peaks were found in the settlement pattern of Acropora corals. This finding supports the hypothesis that even broadcast spawners adopt the strategy of selfrecruitment, at least in a single generation (i.e. settlement pattern was influenced by intrinsic controls such as larval behavior). Otherwise, this short, intensive settlement pattern could be a region-specific event because the result was obtained from only a single reef during a single study year (i.e. extrinsic controls such as hydrodynamics); in this case, these areas should be preferentially designated as 'protected' because such intensive settlement would be important to the resilience of Acropora corals.
\end{abstract}

KEY WORDS: Larval dispersal $\cdot$ Self-recruitment $\cdot$ Mass spawning $\cdot$ Vertical dynamics $\cdot$ Settlement panel

\section{INTRODUCTION}

Most marine animals, even the sessile ones, have a pelagic larval stage in the first part of their life histories. In this stage, extensive exchange of genetic resources and substantial new recruitment from other regions are possible (Caley et al. 1996). Recently, however, it was found that even in the case of species that have the ability for long-range dispersal, recruitment occurs close to the natal place, especially in coral reef fish species (Jones et al. 1999, Cowen et al. 2000, Taylor \& Hellberg 2003; reviewed in Levin 2006, Jones et al. 2009). Self-recruitment has also been reported in reef corals (e.g. Sammarco \& Andrews 1988), but direct evidence for this is still lacking.

Approximately three-quarters of all zooxanthellate corals reproduce via external fertilization (Veron 2000) and have the potential for relative longer-range dispersal than planulae brooders (Nishikawa et al. 2003, but see also Richmond 1987). It is still not clear whether the reproductive strategy of these zooxanthellate corals involves self-recruitment (i.e. short-range dispersal) or broadcasting. Long-range dispersal increases the chances of reaching new unoccupied habitats; nevertheless, larval behaviors and the risk of diffusion and mortality during migration may reduce the feasible range of dispersal from the natal reef (Cowen et al. 2000, Steneck et al. 2009). Although the major role of larval behaviors in the pelagic phase is still unknown, a laboratory experiment demonstrated that coral larvae placed in seawater collected directly above a shallow reef swam downward and began benthic probing, whereas such behavior was uncommon for larvae placed in seawater collected offshore (>50 m depth) (Gleason et al. 2009). This finding may suggest that coral larvae have evolved to maximize dispersal if suitable habitat is not available and/or to minimize the risk of not settling when suitable habitat is available. 
Several population genetics studies (Ayre \& Hughes 2000, Nishikawa et al. 2003, Baums et al. 2005, Underwood et al. 2009) have suggested that in many cases, gene flow between populations is limited in reef corals. For example, genetic subdivisions based on DNA microsatellite data in a spawner, Acropora tenuis, and a brooder, Seriatopora hystrix, between islands $(>100 \mathrm{~km})$, between reefs $(>10 \mathrm{~km})$ or between sites within reefs $(<10 \mathrm{~km})$ in western Australia, indicated that many reefs or reef patches are demographically independent (Underwood et al. 2009). A genetic approach is suitable for assessing population dynamics in an evolutionary time scale, but is not reliable in an ecological time scale. Although new methods such as individual-based assignment tests can be used to identify the natal population of most individuals (Berry et al. 2004), describing larval migration in a single generation is still difficult, especially when genetic divergence among populations is low $\left(F_{\text {st }}<0.1\right)$ (Cornuet et al. 1999). Such genetic studies, therefore, should be validated with direct ecological tests of population connectivity.

Another method for determining the dispersal potential of corals in an ecological time scale is to conduct laboratory experiments that estimate the peak and maximum settlement period (i.e. duration of the pelagic phase) of coral larvae. In 4 Acropora species ( $A$. hyacinthus, A. longicyathus, A. muricata, and A. valida), nearly half of the larvae settled within $1 \mathrm{wk}$ after spawning (Harrison 2006, Nozawa \& Harrison 2008). In other broadcast-spawning species such as Platygyra daedalea, peak settlement occurred between 60 and $66 \mathrm{~h}$ after fertilization (within $3 \mathrm{~d}$ ) (Miller \& Mundy 2003). However, when reared in filtered sea water, the settlement competency period of larvae was several weeks for the following species: 56-63 d for Favites chinensis, 63-70 d for Goniastrea aspera (Nozawa \& Harrison 2005), $26 \mathrm{~d}$ for Cyphastrea serailia, and $78 \mathrm{~d}$ for Acanthastrea lordhowensis (Wilson \& Harrison 1998). Maximum pelagic larval duration ranged from 195 to 244 d in 5 broadcast-spawning corals (Acropora latistella, Favia pallida, Pectinia paeonia, G. aspera, and Montastraea magnistellata), and initial mortality was especially high in A. latistella (Graham et al. 2008). However, these results reflect a problem associated with such laboratory experiments, i.e. that some potential mortality and diffusion factors, such as predation and current, were excluded. To determine if the peak settlement periods suggested by these laboratory experiments represent an in situ duration of the pelagic phase, the settlement pattern should be investigated in the field.

Based on abundance and diversity, Acropora corals form one of the largest taxonomic groups of reef-building corals in the Indo-Pacific Ocean (Veron 2000).
They spawn egg-sperm bundles for a few nights following a late-spring full moon in both hemispheres (Harrison et al. 1984, Hayashibara et al. 1993). Some laboratory experiments have suggested that the settlement competency of Acropora larvae begins from the age of $3 \mathrm{~d}$, peaks at 5 to $7 \mathrm{~d}$, and is maintained over 30 d (Morse et al. 1996, Nishikawa et al. 2003, Harrison 2006, Nozawa \& Harrison 2008). However, the exact peak settlement period of Acropora corals has not been determined; even the shape of the settlement peak (steep or gentle) is unclear. The recruitment pattern of corals, including Acropora corals, has been studied in various spatial scales in different regions with the use of artificial settlement plates (Fisk \& Harriott 1990, Harriott \& Banks 1995, Dunstan \& Johnson 1998, Glassom et al. 2004, Adjeroud et al. 2007). Most of these investigations focused on the seasonal or annual variation in the recruitment pattern rather than on the daily settlement pattern. Hence, no studies have examined the in situ settlement pattern just after a mass spawning of Acropora corals, despite the importance of this pattern in estimating the connectivity of coral populations in a single generation and for selecting protected areas. In this study, the peak settlement period was estimated by counting the number of settled corals every $3 \mathrm{~d}$ after mass-spawning of Acropora corals to determine whether a settlement peak is present or absent and, if present, the timing and duration of the peak. Larval sources are difficult to identify in settlement and recruitment experiments conducted in the field. Therefore, a long-term settlement pattern was also investigated under the hypothesis that some settlement continues intermittently if Acropora larvae from various subpopulations in upstream regions settle sporadically. Concurrently, to determine whether there are species-specific settlement periods, the species composition of the recruited population was analyzed using 2 genetic markers. In addition, the swimming larvae were collected with a plankton net during the settlement period to determine their temporal and spatial distribution in the water column. We assumed that the temporal records of vertical distribution in both recruits and swimming larvae could be used to assess the effect of seawater movement such as surface current and vertical mixing on the settlement pattern of the corals.

\section{MATERIALS AND METHODS}

Peak settlement experiment. The experiment was conducted on the reef slope of Tomino Reef located along the northern shoreline of Ishigaki Island $\left(24^{\circ} 27^{\prime} \mathrm{N}, 124^{\circ} 12^{\prime} \mathrm{E}\right)$, Japan (Fig. 1); the sampling points were at 3 depths: $2.5,5.5$, and $11 \mathrm{~m}$. Tidal ranges 


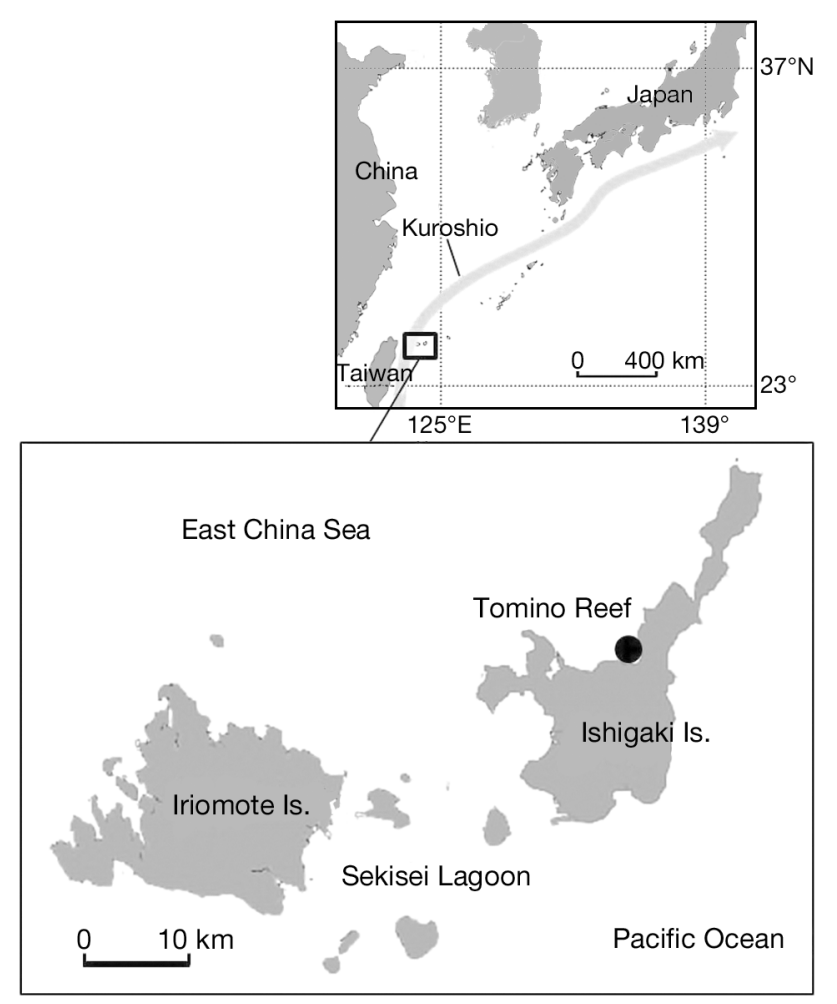

Fig. 1. Study site: Tomino Reef, Ishigaki Island, Japan

in this area during the Acropora mass spawning season are 1.5 to $1.8 \mathrm{~m}$ at flood tide and 0.7 to $1 \mathrm{~m}$ at neap tide. To imitate the complexity of the natural substratum, 2 settlement plates $(7.5 \times 7.5 \mathrm{~cm}$ concrete panels $)$ were arranged vertically; small concrete panels $(3.5 \times$ $3.5 \mathrm{~cm}$ ) were inserted between the plates, separating them by $1 \mathrm{~cm}$. During the experimental period, $5 \mathrm{such}$ pairs were set at each depth. Panels (200) were conditioned in a back reef environment for $10 \mathrm{wk}$ and were relocated to an aquarium (on May 7) prior to the May spawning, where they were maintained until they were installed at the study site. Each time new panels were installed, they were scrubbed with a wire brush to remove filamentous algae that could interfere with larval settlement.

In an average year, the mass spawning of Acropora corals at Ishigaki Island occurs in May on a night near the full moon. In 2009, Acropora corals spawned twice (May and June). Because the settlement pattern is easier to clarify when the new spawning event does not occur during the experimental period, the experiment was conducted in June. The expected spawning day was June 5, so the first panels were set $2 \mathrm{~d}$ earlier (on June 3). The coral eggs in the study reef were checked every morning by randomly sampling 1 or 2 branches from each of 5-10 adult colonies of 3 dominant species (Acropora digitifera, A. hyacinthus, and A. nasuta) at depths of 2 to $10 \mathrm{~m}$ (Suzuki et al. 2008). From the fact that slicks of fertilized eggs were observed and the ovaries of adult corals had been emptied on the morning of June 5, it was established that the spawning occurred on the night of June 4 . The 30 settlement panels ( 5 sets from each depth) were retrieved and 30 replacement panels were installed in the same locations $2,5,8,11$, and $15 \mathrm{~d}$ after the spawning (June 6, 9, 12,15 , and 19, respectively). After June 19, the panels were replaced every $2 \mathrm{wk}$ until September 1 , and then every 4 wk until October 28 (the panels were used repeatedly during these periods).

When the plates were retrieved at short intervals (every $3 \mathrm{~d}$ ), the number of settled corals may be lower than when the plates remained in place for more than 1 week, possibly because of changes in larval behaviors such as substratum exploration (i.e. an underestimation of the number of settled corals on the artificial plates). To assess this underestimation and the number of settled corals in May, the same sets of panels (i.e. an additional 5 sets) were installed on March 23 at the 3 previously mentioned depths $(2.5,5.5$, and $11 \mathrm{~m})$. The panels were then retrieved $19 \mathrm{~d}$ after the spawning in May (June 1) and $15 \mathrm{~d}$ after the spawning in June (June 19).

The retrieved panels were observed under a stereo microscope, and the number of settled corals was recorded. All recruits on the panels were removed using a small knife and stored in guanidine (CHAOS) solution (Fukami et al. 2004) for DNA extraction. To determine whether Acropora recruits exhibit a settlement peak, the number of settled corals between short experimental periods ( 2 to $4 \mathrm{~d}$ ) after mass spawning was compared using the Kruskal-Wallis test, and statistical significance $(\mathrm{p}<0.01)$ was examined using Bonferroni $t$-test for multiple comparisons. The number of settled corals on panels that were replaced was compared with the number of settled corals on panels that were not replaced using the Mann-Whitney $U$ test. All statistical tests were performed using SYSTAT version 11.

Collection of swimming larvae. To study the distribution pattern of swimming larvae of Acropora corals, a diver collected the larvae with a cone plankton net (30 $\mathrm{cm}$ diameter) at 3 depths $(0.5-1,4-6$, and 9-11 $\mathrm{m}$ ) of Tomino Reef in May 2008. Swimming time was $10 \mathrm{~min}$ at a constant speed at each depth (distance of $\sim 300 \mathrm{~m}$ ), and the filtered water volume was $21.195 \mathrm{~m}^{3}$ at each depth. Sampling was conducted every morning 1-5, 7, and $9 \mathrm{~d}$ after spawning. The collected larvae were transferred in to a plastic container on the boat and were returned to the laboratory for counting and observation of developmental stage. Approximately 30 larvae per depth were randomly sampled and preserved for genetic species identification. 


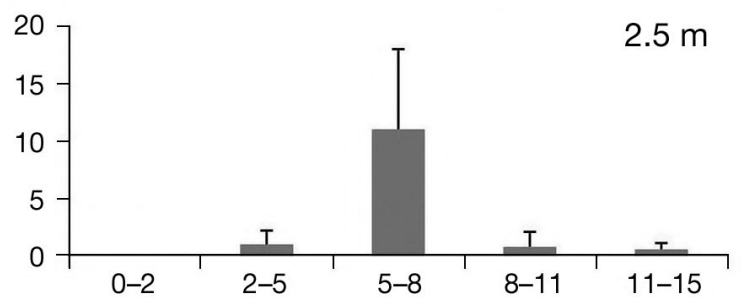

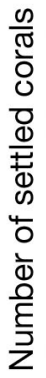
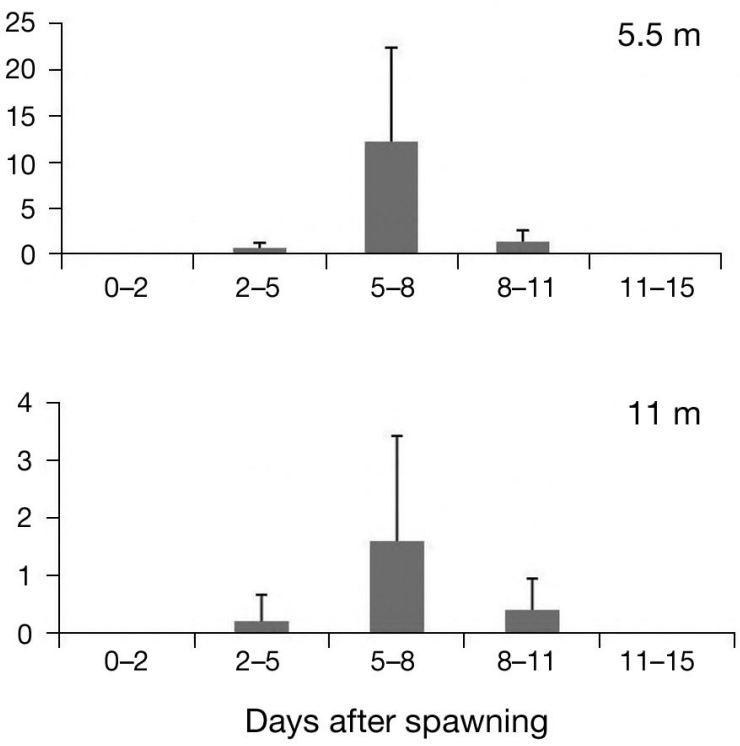

Fig. 2. Number of settled corals per panel set (two $7.5-\mathrm{cm}^{2}$ concrete panels) from 3 depths $(2.5,5.5,11 \mathrm{~m})$ at Tomino Reef after the June 2009 mass spawning event. Panels were retrieved, and conditioned panels (see Materials and Methods) were set $2,5,8,11$, and $15 \mathrm{~d}$ after the mass spawning. Error bars: SD

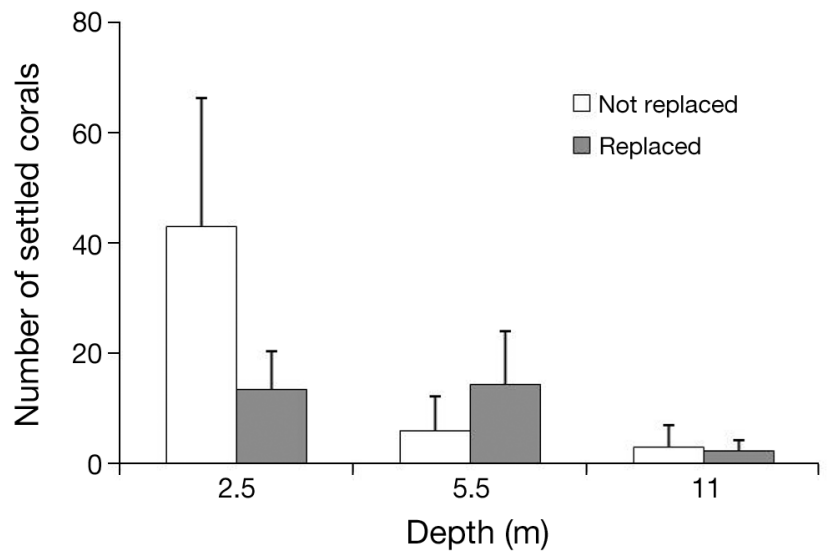

Fig. 3. Number of recruits per panel set retrieved every $3 \mathrm{~d}$ (Replaced) or not retrieved until $15 \mathrm{~d}$ (Not replaced) after the June 2009 mass spawning event, at 3 depths $(2.5,5,5,11 \mathrm{~m})$. Error bars: SD
Genetic species identification. The entire body of the corals that had just settled was digested in $50 \mu \mathrm{l}$ CHAOS solution for several days. Total DNA was extracted from the CHAOS solution by the phenol/ chloroform extraction method (see Suzuki et al. 2008 for the detailed method). A part of the mitochondrial putative control region and the nuclear 5.8S rDNA were used as molecular markers for genetic species identification of Acropora recruits (Suzuki et al. 2008).

\section{RESULTS}

\section{Settlement pattern of Acropora corals}

A total of 149 recruits settled on the settlement panels during the $15 \mathrm{~d}$ period from the mass spawning night in June (June 4). A comparison among 5 periods within $15 \mathrm{~d}$ after spawning showed that a significantly large percentage $(>80 \%)$ of total recruits settled 5 to $8 \mathrm{~d}$ from spawning at all depths (Bonferroni $t$-test, $\mathrm{p}<$ 0.01 ), and $98 \%$ of total recruits settled 2 to $11 \mathrm{~d}$ from spawning (Fig. 2). No recruits were found -1 to $2 \mathrm{~d}$ from spawning or in the latter half of June (15 to $29 \mathrm{~d}$ from spawning). The number of recruits was significantly larger on the panels that were not replaced at the shallow depth (i.e. $2.5 \mathrm{~m}$ ) (Fig. 3). The formations of skeletal elements were incomplete in all specimens on the panels retrieved every $3 \mathrm{~d}$ except for corals that settled 11 to $15 \mathrm{~d}$ from spawning ( 2 of 3 specimens had been completed), whereas most recruits on the panels not retrieved until $15 \mathrm{~d}$ after spawning had already formed skeletal structures.

As observed in other years, the largest mass spawning (based on size and range of observed slicks) around Ishigaki Island was observed a few days after the full moon in May 2009 (May 13). The number of recruits in May, 226.6 \pm 210.5 (mean \pm SD) individuals per panel set (surface area of $176 \mathrm{~cm}^{2}$ ) in the shallow depth, was $\sim 5$ times higher than the number of recruits in June, $42.8 \pm 23.4$ individuals (Table 1 ). No recruits were found between the latter half of June and the first $3 \mathrm{~d}$ of August. Then, 2 recruits per panel set were counted between the first and second half of August (Table 1). In the first half of August, the skeletal structure was incomplete in all specimens, whereas in the second half, it was complete in all specimens and the zooxanthellae infection was confirmed visually in twothirds of all specimens. There were no visible differences in species composition of epibenthic algae on the panels between the retrieval periods.

Comparison of the genetic composition of the settled population between short-term retrieval periods was difficult because the settlement was concentrated in a single period (5 to $8 \mathrm{~d}$ after spawning). The larvae of 
Table 1. Number of settled corals on panels (average number per set of 2 panels) retrieved every 2 or 3 wk, from May to October 2009. Each date represents the day the panels were retrieved. Panels were set at 3 different depths at Tomino Reef on March 23. Data on the panels retrieved on June 19 were obtained from the panels not replaced until $15 \mathrm{~d}$ after the spawning. Mass spawning events were observed on May 13 and June 4. Data: mean \pm SD

\begin{tabular}{|c|c|c|c|c|c|c|c|c|c|}
\hline \multirow[t]{2}{*}{ Depth (m) } & \multicolumn{2}{|c|}{ Jun } & \multicolumn{2}{|c|}{ Jul } & \multicolumn{2}{|c|}{ Aug } & \multicolumn{2}{|c|}{ Sep } & \multirow{2}{*}{$\begin{array}{c}\text { Oct } \\
28\end{array}$} \\
\hline & 1 & 19 & 3 & 21 & 3 & 17 & 2 & 25 & \\
\hline 2.5 & $226.6 \pm 210.5$ & $42.8 \pm 23.4$ & 0 & 0 & 0 & $1 \pm 1.7$ & $0.6 \pm 0.9$ & 0 & 0 \\
\hline 5.5 & $44.6 \pm 31.9$ & $5.8 \pm 6.4$ & 0 & 0 & 0 & $0.8 \pm 0.8$ & $0.6 \pm 1.3$ & 0 & $0.2 \pm 0.8$ \\
\hline 11 & $19.2 \pm 30.0$ & $2.8 \pm 4.1$ & 0 & 0 & 0 & $1 \pm 1.4$ & $0.8 \pm 0.8$ & 0 & 0 \\
\hline
\end{tabular}

the Acropora tenuis group settled only in the first 2 periods (2 to $8 \mathrm{~d}$ after spawning), whereas those of the A. loripes/divaricata group did not settle in June and comprised $\sim 20 \%$ of the settled population in August (Table 2).

\section{Vertical dynamics of swimming larvae}

Only a few swimming larvae were collected at all depths until $3 \mathrm{~d}$ after the mass- spawning event (Fig 4). On the fourth day, 1.4 and 0.8 larvae $\mathrm{m}^{-3}$ were collected at the shallow $(0-1 \mathrm{~m})$ and middle (4-6 m) depths, respectively. At the shallow depth, the number of larvae increased rapidly ( 50 larvae $\mathrm{m}^{-3}$ ) on the fifth day, and then decreased rapidly on the ninth day. In the middle and deep depths, the number of larvae increased on the ninth day. All of the collected larvae swam actively when observed in the laboratory immediately after sampling. The DNA of each of the 246 specimens was analyzed for species identification. All the analyzed specimens were identified as Acropora corals (Table 3); however, because of the large variations in the number of larvae collected and the absence of replication, species composition on the days that the specimens were collected was difficult to compare. Although an agerelated species composition pattern was not evident, a depth-related distributional pattern was observed;

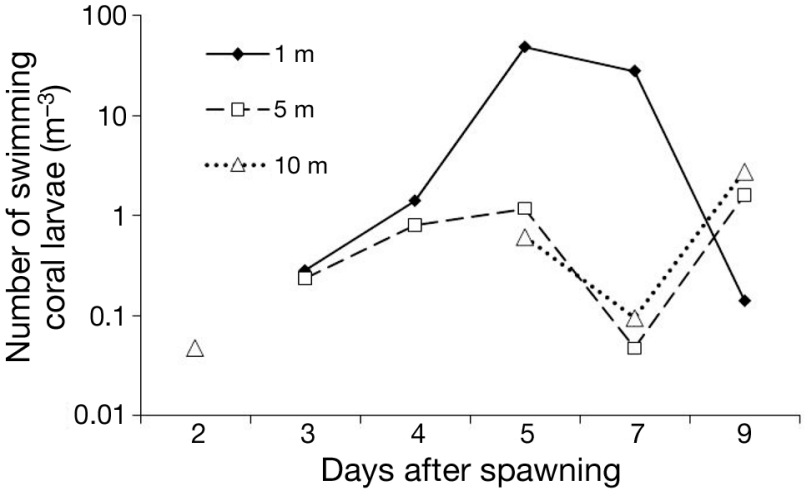

Fig. 4. Change in the number of swimming larvae from 3 depths $(1,5,10 \mathrm{~m})$ at Tomino Reef 2, 3, 4, 5, 7, and $9 \mathrm{~d}$ after the May 2008 mass spawning event. Larvae were collected by a diver using a cone plankton net

A. tenuis larvae concentrated in the middle and deep depths, whereas $A$. digitifera larvae dominated the shallow water (Table 3).

\section{DISCUSSION}

This study is the first to demonstrate the in situ settlement peak of acroporid corals. The peak period was 5 to $8 \mathrm{~d}$ after a mass spawning event: $>80 \%$ of total recruitment occurred during this period (Fig. 2). The number of

Table 2. Genetic composition of settled corals on the settlement panels from June to September 2009. DAS = days after spawning. Represented species groups : Acropora tenuis (TEN), A. digitifera (DIG), A. nasuta (NAS), A. hyacinthus (HYA), A. cytherea (CYT), A. intermedia (INT), A. humilis (HUM), A. loripes (LOR), and A. divaricata (DIV). The dominant percentage of each group is in parentheses $(\%)$. Total $=$ total number of analyzed specimens

\begin{tabular}{|lccccccccc}
\hline \multirow{2}{*}{ DAS } & \multicolumn{1}{c}{ Acropora species group } & \multicolumn{1}{c|}{ Total } \\
\cline { 2 - 5 } & TEN & DIG & NAS & HYA & HYA \& CYT & INT \& HUM & LOR \& DIV & \multirow{2}{*}{ Others } \\
\hline $2-5$ & $3(33.3)$ & $1(11.1)$ & 0 & $2(22.2)$ & $1(11.1)$ & $1(11.1)$ & 0 & $1(11.1)$ & 9 \\
$5-8$ & $7(5.7)$ & $9(7.4)$ & $34(27.9)$ & $5(4.1)$ & $27(22.1)$ & $11(9.0)$ & 0 & $29(23.8)$ & 122 \\
$8-11$ & 0 & 0 & $3(25.0)$ & $1(8.3)$ & $5(41.7)$ & $1(8.3)$ & 0 & $2(16.7)$ & 12 \\
$11-15$ & 0 & 0 & $1(33.3)$ & 0 & $2(66.6)$ & 0 & 0 & 3 \\
$60-89$ & 0 & $4(16.7)$ & $3(12.5)$ & 0 & $8(33.3)$ & $1(4.2)$ & $4(16.7)$ & $4(16.7)$ & 24 \\
\hline
\end{tabular}


Table 3. Genetic composition of swimming coral larvae collected 3 to $9 \mathrm{~d}$ after Acropora mass-spawning (DAS) from 3 depths at Tomino Reef in May 2008. Depths: $\mathrm{S}=$ shallow $(0.5-1 \mathrm{~m}), \mathrm{M}=$ middle $(4-6 \mathrm{~m}), \mathrm{D}=$ deep $(9-11 \mathrm{~m})$. The dominant percentage of each group is in parentheses (\%). Total = total number of analyzed specimens. See Table 2 for Acropora species group abbreviations

\begin{tabular}{|c|c|c|c|c|c|c|c|c|c|}
\hline \multirow[t]{2}{*}{ DAS } & \multirow[t]{2}{*}{ Depth } & \multicolumn{7}{|c|}{ Acropora species group } & \multirow[t]{2}{*}{ Tota } \\
\hline & & TEN & DIG & NAS & HYA & HYA \& CYT & INT \& HUM & Others & \\
\hline \multirow[t]{3}{*}{3} & $\mathrm{~S}$ & 0 & 0 & $1(16.7)$ & $2(33.3)$ & $1(16.7)$ & $1(16.7)$ & $1(16.7)$ & 6 \\
\hline & M & $3(60.0)$ & 0 & $1(20.0)$ & 0 & 0 & $1(20.0)$ & 0 & 5 \\
\hline & $\mathrm{D}$ & - & - & - & - & - & - & - & - \\
\hline \multirow[t]{3}{*}{4} & $\mathrm{~S}$ & $5(16.7)$ & $4(13.3)$ & $7(23.3)$ & $2(6.7)$ & $3(10.0)$ & $3(10.0)$ & $6(20.0)$ & 30 \\
\hline & M & 0 & $2(11.8)$ & $7(41.2)$ & $3(17.6)$ & $5(29.4)$ & 0 & 0 & 17 \\
\hline & $\mathrm{D}$ & - & - & - & - & - & - & - & - \\
\hline \multirow[t]{3}{*}{5} & $\mathrm{~S}$ & $1(2.2)$ & $6(13.3)$ & $8(17.8)$ & $11(24.4)$ & $11(24.4)$ & $2(4.4)$ & $6(13.3)$ & 45 \\
\hline & M & $6(24.0)$ & $3(12.0)$ & $1(4.0)$ & $1(4.0)$ & $3(12.0)$ & $7(28.0)$ & $4(16.0)$ & 25 \\
\hline & $\mathrm{D}$ & $2(15.4)$ & 0 & $1(7.7)$ & $1(7.7)$ & $5(38.5)$ & $2(15.4)$ & $2(15.4)$ & 13 \\
\hline \multirow[t]{3}{*}{7} & $\mathrm{~S}$ & $1(3.3)$ & $1(3.3)$ & $11(36.7)$ & $1(3.3)$ & $11(36.7)$ & $1(3.3)$ & $4(13.3)$ & 30 \\
\hline & M & 0 & 0 & 0 & 0 & $1(100)$ & 0 & 0 & 1 \\
\hline & $\mathrm{D}$ & 0 & 0 & 0 & 0 & $1(50.0)$ & 0 & $1(50.0)$ & 2 \\
\hline \multirow[t]{3}{*}{9} & $\mathrm{~S}$ & 0 & 0 & 1 (33.3) & 0 & 0 & 0 & $2(66.6)$ & 3 \\
\hline & M & $11(32.4)$ & 0 & $2(5.9)$ & $3(8.8)$ & $7(20.6)$ & $6(17.6)$ & 5 (14.7) & 34 \\
\hline & $\mathrm{D}$ & $1(2.9)$ & $1(2.9)$ & 8 (22.9) & $4(11.4)$ & $9(25.7)$ & $10(28.6)$ & $2(5.7)$ & 35 \\
\hline
\end{tabular}

swimming larvae also peaked 5 to $7 \mathrm{~d}$ after spawning and rapidly decreased $9 \mathrm{~d}$ after spawning (Fig. 4). Although these changes in the number of settled corals and swimming larvae might have been affected by oceanic conditions, the weather at that time was mostly stable. A south wind along Tomino Reef produces an offshore surface current that accelerates larval dispersal, whereas a north wind produces an inshore current that concentrates larvae near the reefs. This relationship between wind and surface current in this area was assumed from the annual observation of slick movement and wind direction. Tidal currents were not measured, though these are usually not fast enough to affect the surface current in this reef (G. Suzuki pers. obs.). At the time of the experiments, a north wind prevailed 2 to $3 \mathrm{~d}$ after the spawning, and a south wind (average velocity $<5 \mathrm{~m} \mathrm{~s}^{-1}$ ) continued 3 to $10 \mathrm{~d}$ after the spawning in both 2008 and 2009 (Table A1). Consequently, the sea surface was smooth (wave heights $<0.5 \mathrm{~m}$ ) with little potential for vertical mixing, not only during but also before and after the peak settlement period. Nevertheless, a clear peak settlement was detected 5 to $8 \mathrm{~d}$ after the spawning at all depths, which suggests that larval swimming and settlement is regulated by a mechanism independent of surface currents, or that the effect of surface currents on larval dispersal is limited in the initial 2 to $3 \mathrm{~d}$ after spawning (Nakamura \& Sakai 2010). The underestimated number of settlements on the panels replaced every $3 \mathrm{~d}$ was found only at the $2.5 \mathrm{~m}$ depth at Tomino Reef (Fig. 3), although the reason for this difference is not clear. Yet, this finding does not suggest that the peak settlement period varied between the 2 panel treatments, because most recruits had formed skeletal structures on the panels retrieved $15 \mathrm{~d}$ after the spawn- ing. Although the number of settled corals was $\sim 5$ times higher in May than in June, there was no recruitment just before the spawning in June (i.e. the first observed period). This result also suggested that the larval settlement concentrated in a very short period.

With regard to the long-term settlement pattern after the mass spawning season, the number of recruits was zero until August, when a few recruitments occurred (Table 1). Based on number of individuals only, these few recruits appear to have settled sporadically over 1 mo. However, all recruits in the first half of August (i.e. those retrieved on August 17) had incomplete skeletal structures, whereas most recruits in the second half of August (i.e. those retrieved on September 1) showed visible zooxanthellate infection. Because Acropora larvae begin skeletal formation on the second day after settlement (Hayashibara et al. 1997), the recruits with incomplete skeletons must have settled within $48 \mathrm{~h}$ before retrieval of the panel. Furthermore, because it takes 1 or $2 \mathrm{wk}$ until zooxanthellae within a coral settler are visible to the naked eye (G. Suzuki pers. obs.), the recruits with zooxanthellae must have settled $>1 \mathrm{wk}$ before retrieval of the panel. From these results, it is highly possible that all recruits counted in August settled intensively around the middle of August.

Although the peak settlement period was limited in Acropora corals observed in this study, we cannot conclude that Acropora corals are self-recruiting species because results were obtained from only 1 reef during 1 year. Other hypotheses that explain the settlement patterns are larval migrations from upstream areas with high adult abundance and fecundity during the peak settlement period and/or rapid export of the majority of the larvae from the study site after the peak settlement 
period. At large geographic scales (250 to $400 \mathrm{~km}$ ) in the Great Barrier Reef, Australia, spatial and temporal variations in the fecundity of 3 common Acropora species explained most ( $72 \%$ ) of the variation in recruitment by acroporids (Hughes et al. 2000). Candidate areas for such natal reefs are Sekisei Lagoon and Iriomote Island, located 20 to $40 \mathrm{~km}$ from Tomino Reef, and data on the local connectivity and current regime in this region are required to assess these hypotheses in the future. However, some data supported the hypothesis that dispersal period is limited even in Acropora corals. First, we observed a steep peak and did not detect recruitment from the $15 \mathrm{~d}$ after spawning until August (Table 1). Recruitment likely continued, with a gentle peak or multiple peaks, if Acropora larvae from various subpopulations in various regions settled sporadically. Second, the settled individuals on the panels in August may have originated from areas near Tomino Reef because several species in this region spawn in August and September (Shimada \& Okazaki 1990, Hayashibara et al. 1993, Hayashibara \& Shimoike 2002), although most Acropora species participate in the mass spawning events in May and June. This possibility is supported by the difference in the genetic composition of the recruited population between June and August (Table 2). In addition, these results were consistent with the results of laboratory experiments, which showed that settlement competency peaked $1 \mathrm{wk}$ after fertilization in Acropora corals (Harrison 2006, Nozawa \& Harrison 2008). The results are also consistent with the results of field experiments in western Australia, which showed that A. tenuis larvae dispersed less than 10 to $20 \mathrm{~km}$ even in an isolated system of reefs (Gilmour et al. 2009, Underwood et al. 2009).

Because intensive larval recruitment over a short period may be a key factor in population maintenance and resilience in Acropora corals (i.e. 'demographic connectivity' sensu Kritzer \& Sale 2004), it would be useful information for sustainable management of coral reefs, such as the establishment of marine protected areas. If the 'demographic connectivity' of Acropora corals is relatively smaller than previously thought (i.e. the observed results reflect intrinsic controls such as larval behavior on the temporal patterns of settlement), the establishment of not only one large but also many small protected areas may prove effective. In contrast, the intensive settlement of Acropora corals might be a region-specific phenomenon; that is, extrinsic factors such as the geographical features and tidal current in the northern shore area of Ishigaki Island might have provided the appropriate environment for larval sink. Thus, such areas showing intensive settlement should be selected preferentially as protected areas because they would contribute to the resilience of coral populations and act as a larval source for surrounding areas on a long-term basis (i.e. over several generations).
Acknowledgements. This study was partly supported by a Sasakawa Scientific Research Grant to G.S. (20-706M) from the Japan Science Society.

\section{LITERATURE CITED}

Adjeroud M, Penin L, Carroll A (2007) Spatio-temporal heterogeneity in coral recruitment around Moorea, French Polynesia: implications for population maintenance. J Exp Mar Biol Ecol 341:204-218

Ayre DJ, Hughes TP (2000) Genotypic diversity and gene flow in brooding and spawning corals along the Great Barrier Reef, Australia. Evolution 54:1590-1605

Baums IB, Miller MW, Hellberg ME (2005) Regionally isolated populations of an imperiled Caribbean coral, Acropora palmata. Mol Ecol 14:1377-1390

> Berry O, Tocher MD, Sarre SD (2004) Can assignment tests measure dispersal? Mol Ecol 13:551-561

- Caley MJ, Carr MH, Hixon MA, Hughes TP, Jones GP, Menge BA (1996) Recruitment and the local dynamics of open marine populations. Annu Rev Ecol Syst 27: 477-500

Cornuet JM, Piry S, Luikart G, Estoup A, Solignac M (1999) New methods employing multilocus genotypes to select or exclude populations as origins of individuals. Genetics 153:1989-2000

Cowen RK, Lwiza KMM, Sponaugle S, Paris CB, Olson DB (2000) Connectivity of marine populations: open or closed? Science 287:857-859

> Dunstan PK, Johnson CR (1998) Spatial-temporal variation in coral recruitment at different scales on Heron Reef, southern Great Barrier Reef. Coral Reefs 17:71-81

> Fisk DA, Harriott VJ (1990) Spatial and temporal variation in coral recruitment on the Great Barrier Reef: implications for dispersal hypothesis. Mar Biol 107:485-490

Fukami H, Budd AF, Levitan DR, Jara J, Kersanach R, Knowlton N (2004) Geographic differences in species boundaries among members of the Montastraea annularis complex based on molecular and morphological markers. Evolution 58:324-337

Gilmour JP, Smith LD, Brinkman RM (2009) Biannual spawning, rapid larval development and evidence of self-seeding for scleractinian corals at an isolated system of reefs. Mar Biol 156:1297-1309

Glassom D, Zakai D, Chadwick-Furman NE (2004) Coral recruitment: a spatio-temporal analysis along the coastline of Eilat, northern Red Sea. Mar Biol 144:641-651

Gleason DF, Danilowicz BS, Nolan CJ (2009) Reef waters stimulate substratum exploration in planulae from brooding Caribbean corals. Coral Reefs 28:549-554

Graham EM, Baird AH, Connolly SR (2008) Survival dynamics of scleractinian coral larvae and implications for dispersal. Coral Reefs 27:529-539

- Harriott VJ, Banks SA (1995) Recruitment of scleractinian corals in Solitary Islands Marine Reserve, a high latitude coral-dominated community in Eastern Australia. Mar Ecol Prog Ser 123:155-161

Harrison PL (2006) Settlement competency period and dispersal potential of scleractinian reef coral larvae. Proc 10th Int Coral Reef Symp 1:78-82

- Harrison PL, Babcock RC, Bull GD, Oliver JK, Wallace CC, Willis BL (1984) Mass spawning in tropical reef corals. Science 223:1186-1189

Hayashibara T, Shimoike K (2002) Cryptic species of Acropora digitifera. Coral Reefs 21:224-225

> Hayashibara T, Shimoike K, Kimura T, Hosaka S and others 
(1993) Patterns of coral spawning at Akajima Island, Okinawa, Japan. Mar Ecol Prog Ser 101:253-262

Hayashibara T, Ohike S, Kakinuma Y (1997) Embryonic and larval development and planula metamorphosis of four gamete-spawning Acropora (Anthozoa, Scleractinia) Proc 8th Int Coral Reef Symp 2:1231-1236

Hughes TP, Baird AH, Dinsdale EA, Moltschaniwskyj NA, Pratchett MS, Tanner JE, Willis BL (2000) Supply-side ecology works both ways: the link between benthic adults, fecundity, and larval recruits. Ecology 81:2241-2249

Jones GP, Milicich MJ, Emslie MJ, Lunow C (1999) Self-recruitment in a coral reef fish population. Nature 402:802-804

Jones GP, Almany GR, Russ GR, Sale PF, Steneck RS, van Oppen MJH, Willis BL (2009) Larval retention and connectivity among populations of corals and reef fishes: history, advances and challenges. Coral Reefs 28:307-325

Kritzer JP, Sale PF (2004) Metapopulation ecology in the sea: from Levins' model to marine ecology and fisheries science. Fish Fish 5:131-140

Levin LA (2006) Recent progress in understanding larval dispersal: new directions and digressions. Integr Comp Biol 46:282-297

Miller K, Mundy C (2003) Rapid settlement in broadcast spawning corals: implications for larval dispersal. Coral Reefs 22:99-106

Morse ANC, Iwao K, Baba M, Shimoike K, Hayashibara T, Omori M (1996) An ancient chemosensory mechanism brings new life to coral reefs. Biol Bull (Woods Hole) 191: 149-154

Nakamura M, Sakai K (2010) Spatiotemporal variability in recruitment around Iriomote Island, Ryukyu Archipelago, Japan: implications for dispersal of spawning corals. Mar Biol 157:801-810

Nishikawa A, Katoh M, Sakai K (2003) Larval settlement rates and gene flow of broadcast-spawning (Acropora tenuis) and planula-brooding (Stylophora pistillata) corals. Mar Ecol Prog Ser 256:87-97
Nozawa Y, Harrison PL (2005) Temporal settlement patterns of larvae of the broadcast spawning reef coral Favites chinensis and the broadcast spawning and brooding reef coral Goniastrea aspera from Okinawa, Japan. Coral Reefs 24:274-282

> Nozawa Y, Harrison PL (2008) Temporal patterns of larval settlement and survivorship of two broadcast-spawning acroporid corals. Mar Biol 155:347-351

Richmond RH (1987) Energetics, competency, and longdistance dispersal of planula larvae of the coral Pocillopora damicornis. Mar Biol 93:527-533

Sammarco PW, Andrews JC (1988) Localized dispersal and recruitment in Great Barrier Reef corals: the Helix experiment. Science 239:1422-1424

Shimada H, Okazaki H (1990) Sexual reproduction of scleractinian coral in Amitori Bay, Iriomote Island. BSc thesis, Tokai University, Tokyo (in Japanese)

Steneck RS, Paris CB, Arnold SN, Ablan-Lagman MC and others (2009) Thinking and managing outside the box: coalescing connectivity networks to build region-wide resilience in coral reef ecosystems. Coral Reefs 28: 367-378

Suzuki G, Hayashibara T, Shirayama Y, Fukami H (2008) Evidence of species-specific habitat selectivity of Acropora corals based on identification of new recruits by two molecular markers. Mar Ecol Prog Ser 355:149-159

Taylor MS, Hellberg ME (2003) Genetic evidence for local retention of pelagic larvae in a Caribbean reef fish. Science 299:107-109

> Underwood JN, Smith LD, van Oppen MJH, Gilmour JP (2009) Ecologically relevant dispersal of corals on isolated reefs: implications for managing resilience. Ecol Appl 19: $18-29$

Veron J (2000) Corals of the world. Australian Institute of Marine Science, Townsville

Wilson JR, Harrison PL (1998) Settlement-competency periods of larvae of three species of scleractinian corals. Mar Biol 131:339-345

\section{Appendix 1.}

Table A1. Wind direction and velocity $15 \mathrm{~d}$ after spawning in 2008 and 2009 as recorded at the Ibaruma Observatory $\left(24^{\circ} 30.5^{\prime} \mathrm{N}, 124^{\circ} 16.8^{\prime} \mathrm{E}_{;} \sim 8 \mathrm{~km}\right.$ northeast of Tomino Reef) of the Japan Meteorological Agency. Wind direction represented by the most frequent direction of the day. $\mathrm{N}=$ north, $\mathrm{E}=$ east, $\mathrm{S}=$ south, $\mathrm{W}=$ west. Velocity represented by the average speed $\mathrm{s}^{-1}$.

'-': no observation, *insufficient observation

\begin{tabular}{|lcccc|}
\hline & \multicolumn{2}{c}{2008} & \multicolumn{2}{c|}{2009} \\
& Direction & Velocity & Direction & Velocity \\
\cline { 2 - 4 } Spawning & N & 4.3 & E & 4.3 \\
1 & NNE & 3.5 & N & 3.2 \\
2 & ESE & 3.2 & E & 1.9 \\
3 & SE & 4.3 & ESE & 1.6 \\
4 & SSE & 2.7 & SSE & 3.3 \\
5 & SSE & 2.8 & SSE & 5.0 \\
6 & SSE & 2.0 & S & 4.5 \\
7 & SE & 1.5 & SSW & 4.2 \\
8 & SSE & 2.3 & SSW & 3.1 \\
9 & S & 5.0 & SSW & 3.9 \\
10 & S & 3.3 & - & - \\
11 & N & 2.8 & SSE* & $2.1 *$ \\
12 & NNE & 3.6 & SE & 3.6 \\
13 & ENE & 2.5 & ESE & 4.1 \\
14 & ESE & 1.8 & SSE & 2.9 \\
15 & ENE & 2.2 & NW & 1.6 \\
\hline
\end{tabular}

